Shpinev Iu.S.

$\mathrm{PhD}$ in law, Institute of state and law of the Russian Academy of Sciences, Moscow

\title{
INTELLECTUAL PROPERTY: INVESTMENT ISSUES
}

\section{Summary}

This article discusses the issues of investment in one of the fastest growing industries intellectual property. Considering various normative acts, the author comes to the conclusion that there is currently no single definition of intellectual property and proposes to unify this concept in the Civil and Tax codes of the Russian Federation.

Keywords: investments, intellectual property, capital investments, fixed assets, fixed assets, objects of intellectual activity, exclusive rights, accounting of intellectual property.

At present, no one doubts that investment is essential for the development of the economy of any state. As for Russia, due to the extremely difficult current political and economic factors, as well as the continuing technological lag behind the leading world powers, investment is necessary for our country, as it once was.

Especially important, in the absence of foreign investment, is the issue of attracting domestic investment. Now, in a period of technological progress, innovation and digital technologies, the issue of investment in the results of intellectual activity is extremely important. It is precisely with innovations, innovations that improve the efficiency of management and production processes, and, ultimately, the quality of products, that a breakthrough in the technical and economic direction is associated. President of The Russian Federation Vladimir Putin he has repeatedly stressed that progress in ensuring the quality of life, ensuring the security of Russia and its normal development can only be achieved if the strategy of innovative development is implemented, based on the implementation of human capital and the effective use of people's skills and experience to improve life [1]. Thus, investment in intellectual property is currently one of the most promising and necessary areas.

In order to successfully solve the tasks, set by the President, a regulatory framework should be created that corresponds to the realities of legal relations in the field of investment in intellectual property. At the same time, the legislation should, on the one hand, encourage potential investors to invest their capital in the above-mentioned area, guarantee its inviolability and profit, and ensure transparency of all stages of investment activity. On the other hand, the state must protect its interests by preventing or restricting the admission of not only foreign but also domestic investors to areas where the investment activities of any other persons other than the state itself can cause irreparable damage to the defense, economy or other areas of public life.

It is assumed that such forced restrictions should be transparent, understandable for investors and not contribute to the emergence of a corruption component when making a decision to allow investors in certain areas. At the same time, in our opinion, despite the recent adoption of a number of regulatory acts in the field of investment regulation, the legal framework, especially in the field of investment in intellectual property, still needs to be improved. Recently, the issues of legal regulation of investments in intellectual property are devoted to the work of M. A. Akhmadova [2], L. M. Mikhailova [3], V. V. Pirogova [4], P. p. Battakhov [5], V. A. Urazakova and A.V. Kozlov [6], M. S. Lizikova [7] and others. However, not all issues in this area of investment relations are reflected in these works, and some require more detailed consideration.

In accordance with the Federal law «On foreign investment in the Russian Federation» of 1996, foreign investment is understood as an investment of foreign capital made by a foreign investor in an object of business activity on the territory of Russia in the form of objects of civil 
rights, including those that have a monetary value of exclusive rights to the results of intellectual activity (intellectual property). Thus, this law directly permits foreign investment in intellectual property. According to the Federal law «On investment activities carried out in the form of capital investments» of 1999, capital investments are defined as investments in fixed assets (fixed assets), including the cost of new construction, reconstruction and technical re-equipment of existing enterprises, the purchase of machinery, equipment, tools, inventory, design and survey work and other costs. Thus, the text of the law does not directly indicate its application in relations related to investments in intellectual property. It seems necessary to Supplement the definition of capital investments in fixed assets with intellectual property.

In accordance with paragraph 1 of article 257 of the tax code of the Russian Federation, fixed assets are defined as part of the property used as labor resources for the production and sale of goods (works, services) or for the management of an organization with an initial cost of more than 100,000 rubles. According to clause 3 of article 257 of the tax code of the Russian Federation, tangible assets are the results of intellectual activity and other intellectual property objects (exclusive rights to them) used in production or for management needs for a long time. However, a prerequisite for the recognition of an intangible asset is the ability to generate economic benefits (income). The article will provide an open list of intangible assets. Do not refer to tangible assets, in accordance with the tax code development, technology and scientific research, has not led to a positive result, as well as the skills and ability to work of the staff and their intellectual and business qualities.

It should be noted that the business and intellectual knowledge and skills of employees, as well as their production experience, together with intangible assets used to achieve maximum profit of the enterprise and other economic and technical results constitute intellectual capital. The fourth part of the Civil code of the Russian Federation (hereinafter referred to as the civil code of the Russian Federation), introduced in 2006, is devoted to intellectual property issues. Protected results of intellectual activity and means of individualization are listed in article 1225 of the civil code of the Russian Federation. From July 27, 2020, this list will also be supplemented by geographical indications [8]. It should be noted that the tax code of the Russian Federation refers to intangible assets as exclusive rights, while the civil code of the Russian Federation in the same results of intellectual activity are called intellectual property. Questions of comparative analysis of the concepts of «intellectual property», «exclusive rights», and «intellectual rights» have already been considered by Russian scientists [9]. We can only add that identical definitions of the same concepts in the civil code and tax code of the Russian Federation considerably would facilitate life to participants of investment relations. In addition, you should pay attention that the list of intellectual property in the civil code, although somewhat broader than in the tax code (place names, works of science, literature and art), is closed, while the same list in the tax code makes it possible to interpret it broadly.

Thus, in our opinion, one of the areas of increasing investments in capital projects, is further improvement of the investment legislation, including a unifying definition of intellectual property as intellectual property and intangible rights in the civil code and tax code.

\section{References}

1. Putin V. V. Speech at the expanded meeting of the State Council «On the strategy of development of Russia until 2020». Moscow. Kremlin. February 8, 2008 URL: http://www.kremlin.ru/events/president/transcripts/24 825 (accessed 15.08.2020)

2. Akhmadova M. A. the Legal concept of «Investment» through the prism of the concepts of «property», «intellectual property», «capital» and etc. / / Gaps in Russian legislation. 2018. no. 4. Pp. 154-159.

3. Mikhailova L. M. Problems of foreign investment in Russian enterprises in the form of intellectual property// Young scientist. 2019. No. 37 (275). Pp. 35-37. 
4. Pirogova V. V. Intellectual property: investments and international technological exchange// Bulletin of MGIMO University. 2011. No. 1 (16). Pp. 265-269.

5. Battakhov P. P. the employee's Right to remuneration for using the service result of intellectual activity as a type of intellectual property rights in accordance with part four of the Civil code of the Russian Federation//Jurisprudence. 2010, Vol. 16, No. 4, Pp. 114-120. 6. Urazakova V. A., Kozlov A.V. Intellectual property as an investment object in the process of innovative development of an industrial enterprise. In the collection: Basic and applied research in the field of management, Economics and trade// Proceedings of the scientific and practical conference. 2019. Pp. 119-124.

7. Lisikova M. S. Artificial intelligence in the nuclear industry: application and regulation. In the book: Law and business: legal space for business development in Russia.Collective monograph. In 4 volumes. Editor-in-chief S. D. Mogilevsky [et al.]. Moscow, 2020, Pp. 131-139.

8. Federal law No. 230-FZ of July 26, 2019 «On amendments to part four of the Civil code of the Russian Federation and articles 1 and 23.1 of the Federal law «On state regulation of production and turnover of ethyl alcohol, alcoholic and alcohol-containing products and on restriction of consumption (drinking) of alcoholic products»// Russian newspaper. 2019. \# 166.

9. Battakhov P. P. On the issue of the concept of intellectual property// Gaps in Russian legislation. 2012. No. 5. P. 86-91. 